\title{
CONTENTS OF CLINICAL HEMORHEOLOGY, VOLUME 7, NUMBER 1
}

VOLUME 7, NUMBER 1

SPECIAL ISSUE

Erythrocyte Aggregation

Proceedings of an International Symposium

Geneva, Switzerland 11 January, 1986

\section{CONTENTS}

J.F. Stoltz

A.L. Copley

J.F. Stoltz and M. Donner

P. Boivin

M. Donner, S. Muller and J.F. Stoltz

C. Lacombe and J.C. Lelièvre

M. Lucius and J.F. Stoltz

S. Chien and L.A. Sung

G.B. Nash, R.B. Wenby, S.O. Sowemimo-Coker and H.J. Meiselman J.F. Stoltz, F. Paulus and M. Donner

J.A. Dormandy and G. Nash

M.C. Laprevote-Heully, A. Larcan, P.E. Bollaert, S. Muller, M. Donner, F. Streiff and J.F. Stoltz

J.F. Stoltz and M. Donner

S. Chien
1 Foreword

3 Introduction On Erythrocyte Aggregation and Desaggregation Papers

15 Hemorheology: Importance of erythrocyte aggregation

25 Biochemical parameters of red blood cell deformability

33 Molecular rheology: Definition, approach methods and clinical aspects

47 Interpretation of rheograms for assessing RBC aggregation and deformability

63 Importance of erythrocyte aggregation on the visco-elastic and thixotropic properties of blood

71 Physicochemical basis and clinical implications of red cell aggregation

93 Influence of cellular properties on red cell aggregation

109 Experimental approaches to erythrocyte aggregation

119 Importance of red cell aggregation in venous pathology

123 Hemorheological disturbances during thromboembolic states and various attacks

131 Erythrocyte aggregation: Therapeutic aspects

137 Summary and conclusions

141 Announcement

I Software Survey Section 